\title{
The Role of Humour in Teaching: Teacher Training Students' Image of Teacher and Views on Teaching
}

\author{
Erzsébet SZENTES \\ Sapientia Hungarian University of Transylvania (Cluj-Napoca, Romania) \\ Department of Teacher Training, Târgu-Mureş \\ eszentes@ms.sapientia.ro \\ Zsófia-Irén HORVÁTH \\ Sapientia Hungarian University of Transylvania (Cluj-Napoca, Romania) \\ Department of Teacher Training, Târgu-Mureş \\ horvathzsofia@ms.sapientia.ro \\ Katalin HARANGUS \\ Sapientia Hungarian University of Transylvania (Cluj-Napoca, Romania) \\ Department of Applied Social Sciences, Târgu-Mureş \\ katalin@ms.sapientia.ro
}

\begin{abstract}
A common question in teacher training is what trace is left behind by (many years of) institutional learning, that is, what kind of teacher and teaching image a teacher candidate starts his or her preparation with. The main determinants of becoming a teacher are the experiences gained as a student. The source of their approach and views is personal school experience, which can influence their professional development. In our study, we will discuss how future teachers think about the relationship between humour and school, humour and education. In the initial phase of our study, we asked first-year teacher training students about good and bad teachers in order to gain an insight into their views on teachers' personality and work. After this, we used metaphor analysis to investigate teacher characteristics/qualities that approached the concept of teacher to novel, humorous-playful images. In this phase of our study, we focused on what effective communication tools they have for dealing with tensions and conflicts and the role of humour and playfulness. Not only research (Tisljár 2011; Lazarus, Role, and Genga 2011) but also everyday experience proves that there are a lot of practices in humour that can be learnt and that can shape personality, logic, and memory. The personality of the teacher cannot be formed, or it is very difficult to form, so teacher training has the potential to assist teacher candidates in acquiring skills that help them develop students' cognitive and affective abilities in a fun way.
\end{abstract}

Keywords: humour, education, metaphor analysis, image of teacher 


\section{Introduction}

As practising teachers, we are constantly looking for solutions, methods, and tools that make teaching more effective for us. We are convinced that teachers must constantly strive to use methods and tools that promote or maintain the effectiveness of teaching. As there are no universal, one-size-fits-all solutions that can be applied uniformly for each subject, everyone must strive to find the best way on their own. Our other main direction is to carry out the teaching work effectively and efficiently in our teacher training institute, to prepare our students for this responsible career to the best of our ability.

The effectiveness of using humour has been studied by several researchers (Jonas 2000; Gorham and Christophel 2009; Tisljár 2011; Lazarus, Role, and Genga 2011). In this study, we present surveys that we believe help one consider whether the use of humour is a possible path, a way of teaching in everyday life, an effective tool for increasing school performance and strengthening the teacher-student relationship. We present the forms of humour, its positive and negative effects as well as the role of the use of humour in teacher-student relationship and communication.

\section{The role of humour in education}

According to Cornett (2001), schools and teachers are constantly looking for creative and engaging methods and techniques to make lessons and materials interesting, what allows them to compete with the Internet, the media, and other home entertainment options. Burgess et al. (2000) share this view, i.e. it is important for teachers to make the lesson interesting so that students can master the material and enjoy the lesson. According to Powers (2005), a good teacher inspires students in a variety of ways and makes lessons interesting.

A teacher/educator plans, motivates, analyses, organizes, assesses, pays attention to the content of the curriculum and the teaching methods, but the question of how we teach, that is, the mode, should not be forgotten either (Gorham and Christophel 2009). Owens and Song (2009) also point out that schools focus primarily on methodology, testing, and place less emphasis on optimal educational conditions. According to Chye (2008), there is not enough attention paid to the fact that teacher humour can be an effective way of teaching.

According to Jonas (2000), teachers also consider the use of humour important as humour is an essential feature of a successful teacher. When examining the effect of humour, we do not have to keep in mind what elements make up a joke, that is, we do not have to break it down into its parts as in a classic frog dissection, but we can examine it indirectly. The key to the relationship between humour and school is that the teacher knows when and how it works. 
Humour requires intelligence that involves cognitive skills, divergent thinking and creativity as well as emotional identification and empathy (Tisljár 2011, 2016; Suplicz 2012). The coordinated operation of various processes (e.g. creating and monitoring expectations and associations, recognizing absurdities) is necessary to experience humour (Tisljár 2016).

Having a sense of humour means that we are able to discover contradictions and tensions in things and phenomena; separate the true from the false; dare to play with thoughts and reality. In the case of nonsense, absurdity, we are not waiting for a solution, absolution, or redemption; we are also able to assess that something may be ridiculous just because it has nothing to do with reality at all. ${ }^{1}$ (Pap 2006: 32)

The importance of the sense of humour is also enhanced by the fact that we associate a number of other characteristics with it. For example, according to the research results of Cann and Calhoun (2001), people who are considered to have a good sense of humour are also perceived to be friendly, extrovert, tactful, kind, interesting, imaginative, and intelligent.

Humour can appear in almost all types of our social relationships. The resolution of a humorous situation often culminates in laughter, which relieves tension. The goal of humour in this dissolution is to stabilize the spiritual balance, the self (Bagdy and Pap 2004). Laughter is a response to an interesting, unexpected, novel situation (Latta 1998) and a communication tool for understanding humour. The intensity of laughing reactions is greatly influenced by the current social situation. "Humour changes the patterns and framework of interpretation previously applied to a situation; the individual feels in a lighter, less threatening social environment, with all of its benefits" (Tisljár 2011: 32). According to Owren and Bachorowski (2003), humour and the laughter it generates and the positive emotional state associated with it directly affect the other party's emotional state. At the same time, through the phenomenon of synchronization, the members of the group coordinate quickly and effectively on an emotional level, and this greatly increases the likelihood of effective action for a common goal (Csányi 1998). According to Lovorn (2008), humour plays an important role both in the teacher-student and the parent-child relationship as it provides a significant "feel-good" experience for children. This is the basis of good physical and mental well-being. Children, young people, and adults alike need heartfelt and sticky humour-induced laughter.

According to Garner (2005), the physiological effect of humour is the activation of the right cerebral hemisphere, which stimulates creative thinking and leads to a better assimilation of the material to be learned. According to Lazarus, Role, and Genga (2011), the use of humour has proven to be very effective in increasing

1 The translations from Hungarian specialist literature are my own throughout the article. 
school performance as well as strengthening teacher-student relationship, yet it is often overlooked. A positive relationship between teacher humour and school performance was demonstrated by Hickman and Crossland (2004, Jonas 2000).

Lazarus et al. (2011) identify as positive effects of humour motivating students, making engaging lessons, reducing anxiety, creative thinking and increasing interest, and strengthening the teacher-student relationship. Humour is also an important tool for self-determination, helps to set the limits of the self, and is good for getting rid of fears, worries and dissolving burdensome experiences through laughter (Bönsch and Kauke 1999, Schreiner 2003, Powers 2005). Humour used by teachers has a motivating and liberating power (Neuliep 1991, Pap 2006).

In addition to laughing together, to positive humour as presented above, aggressive, mocking, rude, or hurtful, i.e. negative humour often appears in social situations. Humour that is aggressive, hurtful, and does not pay attention to others causes resentment and negative feelings in the audience, and self-serving humour leads to the assumption of inattention and social insensitivity. Jokes at the expense of others can tune students against the teacher, and humiliating humour puts its user in an abusive role (Tisljár 2011). In education, in a teacher-student relationship, only positive humour that does not offend others can be considered useful (Bagdy and Pap 2004, Pap 2006). Students do not want clownery but a good, stress-free education (Gürtler 2005, Nikitscher 2015).

Jonas (2000) distinguishes between appropriate and inappropriate use of humour. Examples of appropriate humour use are: humour related to the topic or to the teaching material; completely unexpected humour that is not necessarily related to the topic; self-ironic humour, when the subject of the joke is the teacher himself/ herself with his/her mistakes and stumbles; unintentional, unplanned humour. As for inappropriate humour, he mentions offensive and disparaging humour.

At the same time, it is also important to be aware of the risks of positive humour, the relaxed atmosphere and laughter of the class during educational activities. For example, they reduce critical disposition and critical sense (Forgács 2007). It may occur that the use of humour takes the edge off things or makes their truthfulness questionable. Excessive joke and good humour reduce students' sense of duty and discipline, and too much humour can be to the detriment of learning motivation and can eliminate the pedagogical, didactic role we use it for (Gürtler 2005, Nikitscher 2015, Pap 2006). In addition to the loosening of attention and discipline, humour also comes with the emergence of free associations, so restoring the focus of attention to the task will be time-consuming (Suplicz 2012). Applying humour requires responsibility and thoughtfulness from teachers regarding its subject, extent, purpose, and quality.

Thus, the application of humour in school breaks monotony in some situations, relieves tension at other times, can often bring one closer to understanding the material, and laughter with someone else strengthens the sense of community. Humour at school is needed not only for fun and good mood but also because it helps 
us build and maintain relationships, to gain the recognition of the community; it gives us an opportunity to relieve stress, to increase productivity, and channel one's anger and hostile temper in a socially acceptable way.

Humour can be of a great use in a teaching context, and teachers need to learn to be humorous. It is a real task for them to develop their own humour and use laughter as a pedagogical tool (Strom and Ernard 1982, Pap 2006). Numerous studies exploring the expectations of a good teacher's personality and qualities have shown that students value humour in class and value the teacher's sense of humour.

\section{The role of students' image of the teacher and the use of humour in school life}

One of the basic tasks of the Department of Teacher Training at Sapientia Hungarian University of Transylvania is to effectively serve the personal development of students by introducing new pedagogical concepts and procedures. Since 2015, we have been conducting competency-based, diagnostic-type measurements among teacher candidates (Pletl 2015, 2017, 2019) ${ }^{2}$ in order to be able to apply the experiences obtained from the analysis of the results in teacher training covering different specializations.

Part of the first phase of our research was the examination of the image of teacher and the teaching views of teacher training students (Horváth 2015). First-year students $(N=69)$ were asked for their opinion on the criteria of good and bad teachers, using the questionnaire method. We sought the answer to how students, based on their high school experience, characterize good and bad teachers, what they think about teachers' social role. Opinions about teachers were analysed based on open-ended questions. Using an inductive method, we developed four aspects according to the main contents outlined in the answers, and then we grouped the answers. The criteria of analysis: professional expectations and competency, teacher abilities, personality traits, and teacher conduct.

In the case of a good teacher, the most frequently mentioned characteristics were competent, good professional with up-to-date information, varied lessons, effective teaching, and clear explanations. The teachers' skills most often referred to were verbal skills such as good presentation and good speaking skills. In addition to competence, personality traits, such as understanding, determined, patient, helpful, fair, and humorous, were also mentioned.

2 2013-2014: the situation and problems of native language training in relation to teaching (teachers) and learning (high school students).

2015-2016: the situation regarding specialized education in one's mother-tongue: the issue of structure and participation (teachers and students) in a bilingual system.

2017-2018: a study of problem-solving skills regarding different subject areas (reading comprehension, content creation, mathematical and computational thinking). 
In the characterization of a bad teacher, the lack of competence was most often referred to (incomprehensible explanation, no explanation, boring, monotonous lessons). Among teachers' skills, the lack of verbal skills was mentioned (the teacher speaks quickly, does not explain well, he/she is intolerant). The most important personality traits for a bad teacher were impatience, unfairness and insincerity, being aggressive and temperamental, mocking and displaying offensive traits.

An integral part of our research is a survey (carried out over several years) ${ }^{3}$ which explores the concept of teacher among freshman students $(\mathrm{N}=321)$. We scrutinized what prior experiences and views students had regarding their teachers. Teacher trainees' teacher concept (teacher image) has been shaped by their own school experiences and by effects of school problems and different situations involving teachers. In addition, the influences their families and friends had on them during their school years also shaped their views on teachers. The survey was conducted using metaphor analysis. For this, we used a 19-item metaphor list (Vámos 2003a) containing occupations and roles in life. The advantage of a list choice is that it is inevitable to work with metaphors. Compared to the verbalized method, in this case, deeper correlations appear in expressions when a comparison is made between teachers' activities and the ones appearing in the metaphor (Vámos 2003b). The respondents had to select three expressions from the list that they felt were most similar to their view over teaching.

During the analysis, the frequency of source concepts (metaphors) was taken into account. Most often, the metaphors of parents, coaches, and tourist guides were marked in the list, so students were more likely to discover traits characteristic of parents, coaches, and tourist guides in teachers' activities. The parent metaphor was marked by $75.7 \%$ of the students, the coach by $43.6 \%$, and the tourist guide by $38 \%$ of them. Based on the work of Vámos (2003a), this shows that teacher's activity is considered to be mainly of a caring/shaping, directing/guiding, and leading/guiding nature. At the same time, a teacher's activity is considered to be less formative - shaping and of a judgmental nature, but it is not considered possessive - , transmitting, and of a serving nature.

The concept of teacher emerging from the metaphor analysis corresponds with the image of teacher outlined in our previous study as a competent teacher with upto-date information who is able to provide appropriate guidance and thus become a trusted leader. Similarly, an understanding, patient, helpful, and fair teacher can play a caring, personality-shaping parenting role in students' lives.

Our research in the second semester of the 2019/2020 academic year ${ }^{4}$ focused on the role of humour used in teaching. We conducted a questionnaire survey which examined students' view from two perspectives: on the one hand, how they think about the relationship between humour and school as well as humour and education

4 2019: Introduction of modern educational technology methods in teacher training. 
and, on the other hand, how they see the role of humour, playfulness in managing conflicts and tensions, in effective teacher communication, good collaboration, and effective learning.

The main aspect in selecting the sample was that students should already have practical knowledge related to general teaching and specific professional qualifications. Accordingly, the student sample consisted of third-year teacher trainees of Sapientia University $(\mathrm{N}=61)$. They are the ones who have got acquainted with teachers' work, planning the teaching process and gained experience in teaching their subjects during the lesson attendance in the first semester.

Building on the results of our previous research, in compiling the questionnaire, we focused on measuring the positive (17 items) and negative (13 items) effects of humour in the teaching-learning process with a separate set of questions. Students had to rate on a 5-point scale ( 1 - not at all, 5 - completely) to what extent they agreed with the statements about positive and negative humour.

According to the students, positive humour makes the lesson more interesting and relieves the feeling of boredom. They consider that students are calmer and ask questions more boldly during classes when the teacher is funny and has a good sense of humour. As for other characteristics, they also emphasized that a humorous teacher is more appealing than a non-humorous teacher, but they believe that teachers' humour does not necessarily increase students' learning motivation or school performance; nor do they fully agree that humour is an effective tool of explaining difficult-to-understand materials.

On the other hand, they consider that the use of hurtful, critical humour in classrooms destroys the teacher-student relationship. They agree that when teachers use humour in order to humiliate, it increases shame and does not lead to collaboration. In their view, participation in the class is moderately influenced by the teacher's use of offensive, ironic humour. Therefore, they think it is less stressful if the teacher says jokes in class and (s)he is not interested in how students receive them.

With our next set of questions, we examined what students consider important in the communication with effective teachers and where the factors of humour and playfulness are located within this context. Students were required to rate on a scale of 1 to 5 ( 1 - not at all important, 5 - very important) the importance of the following communication characteristics in teacher activities aimed at developing learning skills and arousing students' interest: listens to students; flexible; communicates well; explains logically; highlights the point well; formulates good questions; fair; consistent; can maintain discipline/is strict; friendly, kind; direct; playful; has a good humour; patient; lively; active. The average scores of the communication factors evaluated by the students are shown in tables: the values considered to be the four most important characteristics, the averages of humour and playfulness.

Our first question was related to how important certain communication features are in order to develop a friendly, tension-free, good atmosphere and a cooperative 
partnership between the teacher and the students (Table 1). According to students, in order for the teacher to create a good work atmosphere in class, the most important thing is to listen to the students, communicate well, explain logically, and highlight the points. Good humour is also important, but they take into account that an appropriate learning environment cannot be created without a comprehensive awareness towards students and without proper communication.

Table 1. Good work atmosphere in class

\begin{tabular}{lc}
\hline Characteristics of communication & Average \\
\hline listens to students & 4.80 \\
\hline communicates well & 4.67 \\
\hline explains logically & 4.64 \\
\hline highlights the points well & 4.62 \\
\hline has good humour & 4.28 \\
\hline is playful & 3.70 \\
\hline
\end{tabular}

Our next question measured the emphasis on communication factors in dealing with classroom conflict situations (Table 2). Attention, justice, and good and consistent communication are the most important aspects when dealing with conflict situations. Good humour and playfulness are only given medium importance; so, in the respondents' view, they do not play such a significant role in these situations.

Table 2. Conflict management in the classroom

\begin{tabular}{lc}
\hline Characteristics of communication & Average \\
\hline listens to students & 4.90 \\
\hline is fair & 4.84 \\
\hline communicates well & 4.75 \\
\hline is consistent & 4.62 \\
\hline has good humour & 3.51 \\
\hline is playful & 3.08 \\
\hline
\end{tabular}

With our third question, we examined what communication characteristics a teacher can use to encourage students to collaborate (Table 3). Listening, good communication, flexibility, and patience were considered very important in encouraging collaboration between students, but humour and playfulness also play an important role in the development of student interaction in the teachinglearning process. 
Table 3. Encouraging collaboration between students

\begin{tabular}{lc}
\hline Characteristics of communication & Average \\
\hline listens to students & 4.70 \\
\hline communicates well & 4.69 \\
\hline is flexible & 4.52 \\
\hline is patient & 4.52 \\
\hline has good humour & 4.07 \\
\hline is playful & 4.00 \\
\hline
\end{tabular}

With our following question, we looked into the characteristics of communication that teachers can use to increase students' learning motivation (Table 4). Highlighting the essence of the content, logical explanation, and formulating good questions are the most important features in enhancing and strengthening learning motivation, but at the same time good humour also plays an important role.

Table 4. Increasing learning motivation

\begin{tabular}{lc}
\hline Characteristics of communication & Average \\
\hline highlights the points well & 4.72 \\
\hline explains logically & 4.70 \\
\hline communicates well & 4.67 \\
\hline asks good questions & 4.66 \\
\hline has good humour & 4.28 \\
\hline is playful & 3.98 \\
\hline
\end{tabular}

Next, we examined the communication characteristics that help students to develop respect for the teacher (Table 5). Fairness, attention paid to students (listens to students), consistency, and discipline are the most important characteristics in triggering respect. Good humour and playfulness are only of medium importance in the development of a sense of mutual respect.

Table 5. Respect for the teacher

\begin{tabular}{lc}
\hline Characteristics of communication & Average \\
\hline is fair & 4.85 \\
\hline listens to students & 4.82 \\
\hline is consistent & 4.74 \\
\hline can maintain discipline/is strict & 4.61 \\
\hline has good humour & 3.72 \\
\hline is playful & 3.46 \\
\hline
\end{tabular}


With our last question, we measured what communication characteristics are needed for the teacher to help students understand the material (Table 6). In order to ease the material to be learned, communication skills were given priority: logical explanation, highlighting the points, asking good questions. According to students, good humour and playfulness are moderately important in understanding the information to be mastered.

Table 6. Understanding the material to be learned

\begin{tabular}{lc}
\hline Characteristics of communication & Average \\
\hline explains logically & 4.93 \\
\hline highlights the points well & 4.92 \\
\hline asks good questions & 4.82 \\
\hline communicates well & 4.80 \\
\hline has good humour & 3.89 \\
\hline is playful & 3.70 \\
\hline
\end{tabular}

We summed up the average values of good humour and playfulness in the function of different communication situations (Table 7). On the whole, we can state that humour plays an important role in creating a good work atmosphere, strengthening learning motivation, and stimulating collaboration among students. Students do not attach much significance to humour in conflict management. Playfulness is not considered essential in conflict management or in developing mutual respect.

Table 7. Average values of humour and playfulness

\begin{tabular}{lcc}
\hline In order for the teacher to & good humour & playfulness \\
\hline create a good work atmosphere in the class & 4.28 & 3.70 \\
\hline handle conflict situations in the classroom & 3.51 & 3.08 \\
\hline encourage students to collaborate & 4.07 & 4.00 \\
\hline increase students' learning motivation & 4.28 & 3,98 \\
\hline elicit respect from his/her students & 3.72 & 3.46 \\
\hline help to understand the material to be learned & 3.89 & 3.70 \\
\hline
\end{tabular}

Every teacher should be able to communicate assertively, that is, with sufficient confidence, to express their feelings and thoughts without behaving aggressively or submissively. Assertive communication depends primarily on the communicator's confidence, positive self-image, and empathy. This means that the communicator can express his/her needs, express his/her opinions and feelings accurately while striving for a positive conclusion of his/her cooperation with the communication partner so that the communication can be successful for both parties. Assertive behaviour, which promotes equality in relationships, enables people to stand up for their interests without anxiety, to express their feelings and thoughts freely (Bishop 
2008). However, there are a number of situations when it is difficult to be assertive such as when making or refusing a request, criticizing, expressing, or receiving an opinion, making or receiving praise, clarifying unjust accusations, or dealing with conflict situations (Németh 2002). The educational effects reach the students through the teacher-student relationship. Both student performance and the success of the teacher's work are greatly influenced by the quality of the teacher-student relationship, which is well founded by empathic treatment and which is largely determined by assertive behaviour and good communication (Bábosik 2003).

The average scores given on the basis of student evaluations allow us to conclude that they recognize that humour and playfulness are effective regulatory tools for effective communication. Overall, the role of the named communication characteristic in different school situations was very well considered, and thus the role of humour was also weighed thoroughly. Respondents consider humour important, but they do not forget about attentive behaviour, about logical explanation, or the necessity of highlighting the essence of the content.

\section{Discussion and conclusions}

In the initial phase of our study, we asked first-year teacher training students for their opinions on good and bad teachers in order for us to learn about their views on teachers' personality and work. We asked them to list the criteria of a good and a bad teacher. By grouping and analysing the answers, in addition to competence and good communication skills, students most often wrote qualities as funny, humorous, or having a good sense of humour (Horváth 2015).

Furthermore, we examined teacher characteristics using metaphor analysis, in which students approached the concept of teacher with novel, humorous-playful expressions. Based on these, students consider the teaching activity to be mainly caring/shaping, directing/guiding, and leading/guiding. The teacher concept outlined on the basis of the results of the two examinations shows identity. The respondents' answers revealed that they prefer an understanding, patient, fair, wellprepared teacher with good communication skills and with a good sense of humour, one who has caring, shaping, guiding, and leading traits.

In the present phase of our study, we focused on how our teacher training students think about the relationship between humour and education. The data obtained suggest that, according to our students, non-destructive versions of humour may be very useful in the teacher's work as well. It strengthens the teacher-student relationship, but applying it to lessons is not always the most effective step. Tense situations can be resolved with the help of humour, but in the meantime loosening of attention and discipline must also be taken into consideration. Humour has a beneficial effect if the "we laugh with you and not at you" experience prevails, 
where the goal is not making the students look ridiculous (Suplicz 2012). Teacher trainees find humour and playfulness most useful in encouraging collaboration and interaction between students, creating a good classroom atmosphere, and arousing interest for learning, but respondents' answers show that, in fact, in each of the situations examined, teachers may benefit from the use of positive humour and playfulness in educational work.

It is indisputable that proper, positive humour used by the teacher has a good effect on establishing and maintaining a trusting teacher-student relationship and good cooperation, an efficient management of conflict situations and pedagogical problem situations in general, creating discipline and a good work atmosphere, helping to understand the material to be learned, and maintaining learning motivation. However, all these require not only a sense of humour but also teachers' assertive behaviour and the use of effective communication strategies. As it can be seen in the opinions of teacher candidates, good humour is not a substitute for professional and methodological competence or for basic competencies such as communications skills, problem-solving skills, and decision-making skills.

When using teacher/classroom humour, the sense of proportion should also be taken into account as too much humour as well as a humour-free, boring lesson distracts attention from the material to be learned and slows down the teachinglearning process. In case of too much and inappropriate humour, the focus of attention should always be shifted back to the lesson. On the other hand, maintaining interest is difficult to achieve during boring, monotonous, humour-free lessons. Humorous tone often takes the edge off the communication situation, making it playful. It can also play an important role in the relationship between teachers and students as it dissolves negative emotions and brings people closer to each other.

By succeeding in arousing interest in their subjects, teachers can initiate a process of cognitive development in adolescent personality that can be the basis for outstanding school performance. Teachers can achieve a lot with humour as a specific way of communication, but only jokes, puns, examples, or feedback that do not harm the children's/students' selves can be used.

The results of our survey provide a basis for preparing students for new expectations in education and for implementing quality education. Our research forms a starting point for further investigations, and we plan to compare the views of students with the educational experiences of teachers working in high schools. This would provide a solid basis for building continuity between the different training levels (issuing high school - teacher training - return to high school). 


\section{References}

Bábosik, István. 2003. Alkalmazott neveléselmélet [Applied Educational Theories]. Budapest: Okker.

Bagdy, Emőke-János Pap. 2004. Gondolatok a nevetésről [Thoughts about laughter]. Psychiatria Hungarica 11(5): 390-418.

Bishop, Sue. 2008. Asszertivitás [Assertiveness]. Budapest: Manager.

Bönsch-Kauke, Marion. 1999. Witzige Kinder. Zur spielerischen Entwicklung von humorvollen Interaktionen zwischen sieben-bis zwölfjährigen Kindern durch kreative Techniken. Zeitschrift für Entwicklungspsychologie und Pädagogische Psychologie 31(3): 101-115.

Burgess, Ron-Cynthia Nelson-Darsi Dreyer. 2000. Laughing Lessons: 149 2/3 Ways to Make Teaching and Learning Fun. Minneapolis: Free Spirit Publishing Inc.

Cann, Arnie-Lawrence G. Calhoun. 2001. Perceived personality associations with differences in sense of humor: Stereotypes of hypothetical others with high or low senses of humor. Humor: International Journal of Humor Research 14(2): 117-130.

Chye, Eng Tan. 2008. The Need for Effective Teaching. NUS Press: National University of Singapore.

Cornett, Claudia. 2001. Learning through Laughter... Again. Bloomington: Phi Delta Kappa Educational Foundation.

Csányi, Vilmos. 1998. Az emberi természet. Humánetológia [Human Nature. Human Ethology]. Budapest: Vince.

Forgács, József. 2007. A társas érintkezés pszichológiája [The Psychology of Social Interaction]. Budapest: Kairosz.

Gorham, Joan-Diane M. Christophel. 2009. The relationship of teachers use of humor in the classroom to immediacy and student learning. Communication Education 39: 45-62.

Hickman, Gregory P.-Garnet L. Crossland. 2004. The predictive nature of humor, authoritative parenting style, and academic achievement on indices of initial adjustment and commitment to college among college freshmen. Journal of College Student Retention Research Theory and Practice 6(2): 225-245.

Horváth, Zsófia-Irén. 2015. A tanárképzős diákok tanárképe [Teacher training students' image of practising teachers]. In Rita Pletl (ed.), Anyanyelvoktatás. A magyar tannyelvú szakközépiskolai oktatás helyzete [Native Language Education. The Situation of Hungarian Language Vocational Education], 89-96. Cluj-Napoca: Ábel.

Latta, Robert L. 1998. The Basic Humor Process: A Cognitive-Shift Theory and the Case against Incongruity. Berlin: Mouton de Gruyter. 
Lazarus, Ndiku Makewa-Elizabeth Role-Jane Ayiemba Genga. 2011. Teachers' use of humor in teaching and students' rating of their effectiveness. International Journal of Education 3(2): 1-17.

Németh, Erzsébet. 2002. Az önismeret és a kommunikációs készség fejlesztése [Developing Self-Knowledge and Communication Skills]. Budapest: Századvég.

Neuliep, James W. 1991. An examination of the content of high school teacher's humor in the classroom and the development of an inductively derived taxonomy of classroom humor. Communication Education 40(4): 343-355.

Nikitscher, Péter. 2015. A pedagógusok szerepe és lehetőségei az iskolai szocializáció folyamatában [The role and opportunities of educators in the process of school socialization]. In Péter Nikitscher (ed.), Az iskola szocializációs szerepe és lehetöségei [The Role of School Socialization and Possibilities], 56-80. Budapest: Oktatáskutató és Fejlesztő Intézet.

Owren, Michael J.-Jo-Anne Bachorowski. 2003. Reconsidering the evolution of nonlinguistic communication: The case of laughter. Journal of Nonverbal Behavior 27(3): 183-200.

Pap, János. 2006. Puer ridens. Humor az iskolában [Puer ridens. Humor at school]. Új Pedagógiai Szemle 56(5): 25-34.

Pletl, Rita. 2015. A vizsgálat általános bemutatása [General presentation of the study]. In Rita Pletl (ed.), Anyanyelvoktatás. A magyar tannyelvú szakközépiskolai oktatás helyzete [Native Language Education. The Situation of Hungarian Language Vocational Education], 8-22. Cluj-Napoca: Ábel.

- 2017. A vizsgálat általános bemutatása [General presentation of the study]. In Rita Pletl (ed.), Anyanyelvoktatás: a magyar tannyelvú szakképzés jelene és jövóbeli kilátásai [Native Language Education. The Present and Future Prospects of Vocational Education in Hungarian Language], 9-17. Cluj-Napoca: Ábel.

- 2019. A problémamegoldó képesség országos hatókörú vizsgálata [Examing of problem-solving skills in different fields of education]. In Rita Pletl (ed.), Anyanyelvoktatás. A feladatmegoldástól a problémamegoldásig [Native Language Education. Problem-Solving Skills], 10-25. Cluj-Napoca: Ábel.

Powers, Ted. 2005. Engaging students with humor. Observer 18(12): 13-24.

Schreiner, Joachim. 2003. Humor bei Kindern und Jugendlichen. Berlin: VWBVerlag für Wissenschaft und Bildung.

Strom, Robert D.-Harold W. Bernard. 1982. Educational Psychology. Monterey California: Brooks/Cole Publishing Company.

Tisljár, Roland. 2016. A humor kialakulása és szerepe a kommunikációban [The emergence of humor and its role in communication]. In Petra Gyuris-Norbert Meskó (eds), Evolúciós pszichológia mesterfokon [Evolutionary Psychology in Higher Forms], 306-322. Pécs: Pro Pannonia.

Vámos, Ágnes. 2003a. Metafora a pedagógiai kutatásban [Metaphor in pedagogical research]. Iskolakultúra 4: 109-112. 
— 2003b. Tanárkép, tanárfogalom a családban [Teacher image, teacher concept in the family]. Iskolakultúra 5: 113-119.

\section{Web sources}

Garner, Randy. 2005. Humor, analogy and metaphor in teaching: H.A.M. it up in teaching. Radical Pedagogy 6(2): n.p. http://radicalpedagogy.icaap.org/content/issue6_2/garner.html (Last accessed: 17 April 2020).

Gürtler, Leo. 2005. Humor in der Pädagogischen Psychologie - Innensicht und Außensicht auf lustige und kritische soziale Momente! http://docplayer. org/49732167-Humor-in-der-paedagogischen-psychologie-innensicht-undaussensicht-auf-lustige-und-kritische-soziale-momente.html (Last accessed: 22 August 2020).

Jonas, Peter M. 2000. Laughing and Learning an Alternative to Shut Up and Listen. https://www.worldcat.org/title/laughing-and-learning-an-alternative-to-shut-upand-listen/oclc/1005640515 (Last accessed: 17 April 2020).

Lovorn, Michael G. 2008. Humor in the home and in the classroom: The benefits of laughing while we learn. Journal of Education and Human Development 2(1): 1-12. http://citeseerx.ist.psu.edu/viewdoc/download?doi=10.1.1.558.9235\&rep= rep1\&type $=p d f$ (Last accessed: 17 April 2020).

Owens, Emiel-Holim Song. 2009. The new changing faces of urban teachers and their emerging teaching belief. Online Yearbook of Urban Learning, Teaching, and Research: Urban Learning, Teaching, and Research, 13-28. https://64b8a5decd16-491a-a1d2-fd81682eb956.filesusr.com/ugd/f2a8cd_6f247d8932474bef931a 68d9dec2ed51.pdf (Last accessed: 17 April 2020).

Suplicz, Sándor. 2012. Tanárok pszichológiai jellemzôi diákszemmel [Psychological Characteristics of Teachers through the Eyes of Students]. https://dea.lib. unideb.hu/dea/bitstream/handle/2437/161946/suplicz_sandor_ertekezest. pdf?sequence $=5$ (Last accessed: 17 April 2020).

Tisljár, Roland. 2011. A humor szerepe és szerveződése a társas kapcsolatokban. Evolúciós modellek tesztelése [The Role and the Organization of Humour in Social Relations. Testing Evolutionary Models]. https://pea.lib.pte.hu/bitstream/ handle/pea/15278/tisljar-roland-phd-2011.pdf?sequence=1EisAllowed=y (Last accessed: 17 April 2020). 